\title{
THE ACCOUSTIC OBSERVATION AND THE EXPLOITATION OF THE PURSE SEINE FISHERY IN THE JAVA SEA
}

\author{
Duto Nugroho"1), Bonar P. Pasaribu' ${ }^{2)}$, and Vincent P. Siregar ${ }^{2)}$ \\ 1) Research Institute for Marine Fisheries, Muara Baru-Jakarta \\ 2) Department of Marine Science and Technology, Faculty of Fisheries and Marine Science, Bogor Agricultural University, Bogor \\ Received June 13-2008; Received in revised form June 16-2008; Accepted June 27-2008
}

\begin{abstract}
Several acoustic surveys were carried out during a period of 1992 to 1995 in the main fishing ground of the pelagic fishery in the Java Sea. The collaboration between Indonesia and French made up within the frame of Pelfish Project. The improvement of the useful information of offshore pelagic fish resource in the Java Sea by the acoustic technique was applied to study the magnitude of the pelagic fish resource exploited by the purse seiners. This paper describes a general results based on a relatively consecutive surveys with related to spatial acoustic population exist in the Java Sea The exploitation pattern of the pelagic fishery represented by the catch of the purse seine fishery was also taken into account as comprehensive data to evaluate the existing resources. The results showed that there are longitudinal gradient densities in the middle part of the middle part of the Java Sea. Specific observation on fish schools showed that there was a different occurrence in density and its relative dimension related to the season.
\end{abstract}

KEYWORDS: accoustic, exploitation, purse seine, fishery, Java Sea

\section{INTRODUCTION}

The application of fisheries acoustic has a long history of fishery work on various seawaters in Indonesia. The system was established in order to study the abundance of pelagic fish resource. Java Sea as a part of the eastern part of Sunda Shelf with approximately of $450.000 \mathrm{sq}$. $\mathrm{km}$., which morphologically well delimited with Sumatera, Java, and Kalimantan Islands. The eastern boundary is wide open towards deep Flores Seas and Makassar Strait. The average depth was $40 \mathrm{~m}$ with bottom slopes from 20 to $100 \mathrm{~m}$ from west to east. The environment controlled by a monsoonal cycle.

The estimation of total production of small pelagic fish from the area reached 443.000 tons in 1997 (Mertha et al., 1998). The main target species in the open waters consisted of round scads (Decapterus macrosoma and Decapterus ruselli), pacific mackerel (Rastrelliger kanagurta), big eye scads (Selar crumenopthalmus), Sardine (Sardinella gibbosa), and spotted sardine (Ambligaster sirm) (Durand, 1997). The pelagic fishery in the area existed since early 1970 's and previous study stated that the catch fluctuated according to the monsoon (Potier \& Sadhotomo, 1995). General results of the cruise were already published by authors in the last Proceeding of Akustikan II and give an indication that generally the densities were higher during southeast monsoon with the highest concentration were found in the eastern part of the Java Sea (Petit et al., 1997).

This paper veal with the variability of acoustic densities of fish schools and related to the environmental changes represented by profiles of the temperature and salinity. Objectives and scope of this paper were aimed to describe the characteristics pelagic fish resources based on the acoustic abundance and the catch data that have been collected in main landing places in the North coast of the Java Sea.

\section{MATERIALS AND METHODS}

R/V. Bawal Putih I (31.2 m LOA; 192.2 GT all steel stern trawl) was used during the survey. An acoustic equipment and procedure have been used in different sub areas and years. Transecting with towed body down looking transducer placed at 1.5 to $2.0 \mathrm{~m}$ depth was made all observation of the primary data collection. The scientific sounder of dual-beam ( $7^{\circ}$ narrow and $18^{\circ}$ wide circular beams) Biosonics model 102 working with a frequency of $120 \mathrm{kHz}$ was applied during the surveys. The acoustic characteristics of the equipment was controlled previously on a standard tungster, ball of a $-41 \mathrm{~dB}$ reflection index.

A set of acoustic characteristics is selected and data were collected. This study mainly focussed on the data generated via an interphase of INES MOVIES that triggered the echo sounder and produced echogram to provide the relatives abundance. Detail operation and processing the acoustic data described by Petit et al. (1997). Essentially the data processed in a series of time giving a set data profile by layers between near surface to the bottom. The data were 
averaged over one $\mathrm{nm}$ of sailing with a speed around 5 to 6 knots.

There are several themes of the surveys, among them two different activities were explored to study the seasonal variation on the fish densities performed by transect island to island from Semarang to Matasiri Island. The large scale survey covering the deep water (>50 m) carried out in October 1993 and February
1994 allowed to have a general distribution of the density and to evaluate the mean density during different seasonal condition. The data were collected through a series of parallel grid pattern with transects running north southward direction. The geographical boundaries were between $4^{\circ} 30^{\circ}-7^{\circ} \mathrm{S}$ latitude and $112^{\circ}$. $116^{\circ} \mathrm{E}$. An illustration of the survey grid and the area coverage is shown in Figure 1.
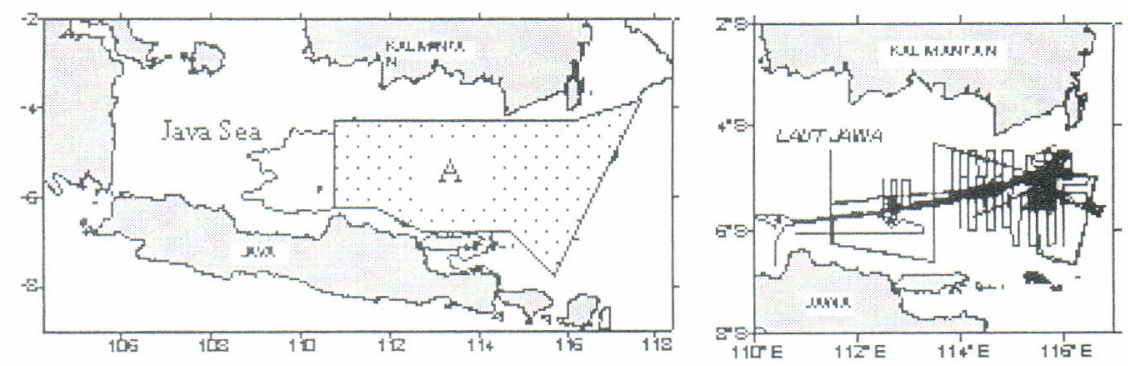

Figure 1.

The main fishing ground of purse seine fishery in the Java Sea.

Remarks: $A=$ Area of study; and the survey cruise tracks

We considered that 10 cruises were used as a database to study. Each cruise was taken relatively represented the seasonable occurrence of the pelagic fish in the area of interest. The detailed operational aspects of the survey were published elsewhere (see Petit et al., 1997).

The acoustic data from each cruise were analyzed graphically and then mapped and combined with all the information available on the proportion of catch data of pelagic fish from commercial fisheries to translate the acoustic phenomenon into the corresponding natural fish communities.

\section{RESULTS AND DISCUSSIONS}

\section{Environmental Conditions}

The environmental changes of the Java Sea are governed by the monsoonal cycle, which affect on their hydrological conditions. A series of 1992 to 1994 of environmental variables, such as temperature, salinity were collected through deployment of seabird profiler. Selected stations that located in the eastern part of the Java Sea were taken as a sample represented of the main area of fishing ground. These stations were analyzed to describe the general variability of the environment. The results show that the salinity and temperature values varied seasonally, where the highest salinity with the lowest temperature occurred in September and October 1992 and October 1993. This period represented the influence of entrance of the oceanic waters to the eastern part of the area. The lowest salinity with high temperature occurred in May and June, November and December 1992 November and December 1993, and February 1994. These conditions represented that the influence of oceanic waters were very low and the influence of the terrestrial conditions plays a significant role.

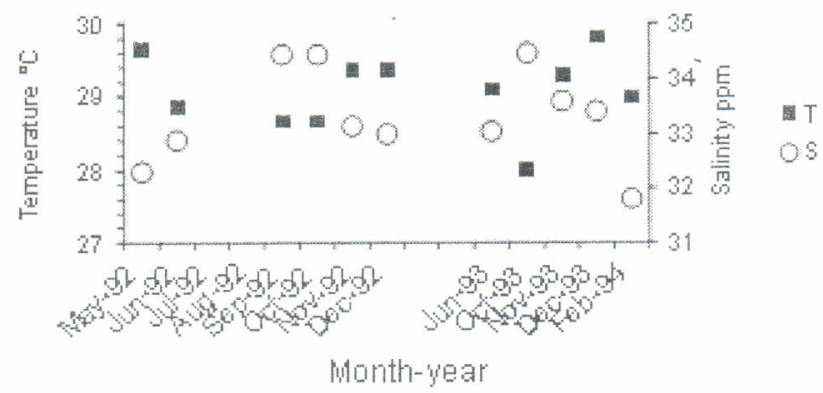

Figure 2. Monthly changes ot sea surtace temperature and salınıty ın the eastern part of the Java Sea. 
The scatter plot of monthly temperature and salinity indicated a statistically significant between the late of southeast (September, October) and norihwest (May, June and November, December) monsoons (Figure 2). Generally, the global changes of the environment indicated that during dry season the sea surface temperatures were gradually decreased from May to October 1992 within a range between 29.8 to $28.6^{\circ} \mathrm{C}$ and the surface salinity increased from 32.0 to $34.5 \mathrm{ppm}$. The reverse condition occurred in the wet season from November to February. These phenomena have been clarified by Veen (1953); Wyrtki, (1961).

Monthly catch of purse seine fishery operated in the main fishing ground fluctuated according to the climatic year which composed of two main seasons due to monsoon winds: a wet season (November to February) and a dry season (July to October). During the interseasonal changes, the condition of the preceding season continues until the wind is stable enough to bring out the reverse situation.

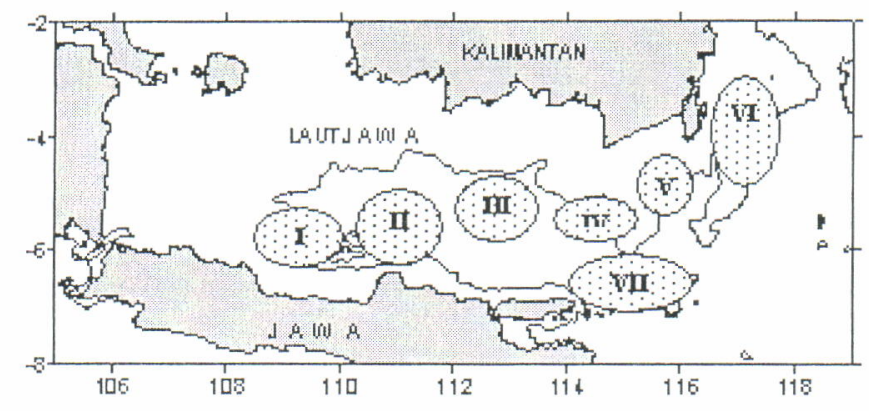

Figure 3. The main fishing ground of purse seine fishery in the Java Sea. Sources: Boely et al. (1992) Remarks:I. North of Tegal; II. Karimun Jawa is; III. Bawean is; IV. Masalembo is; V. Matasiri is; VI. Lumu-lumu is/Makassar Strait; VII. Kangean is

\section{Fishery Synthesis}

As in most of the tropical Asian pelagic purse seine fisheries, the exploitation characteristics of the pelagic fish resource is using fish aggregation device and light attraction to concentrate the fish. Since the implementation in 1971, the purse seine fisheries continuously extend their fishing ground. The strategy of large seiners is to change their fishing ground according to the environmental conditions and to the

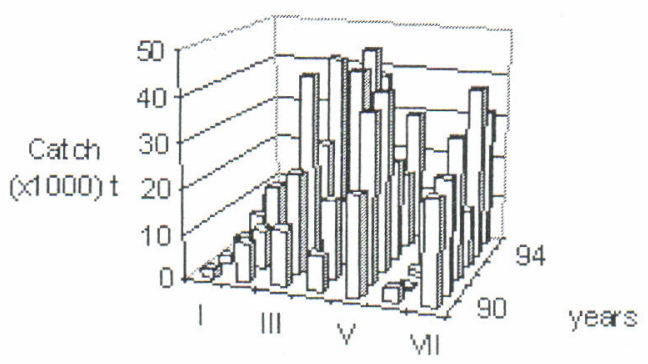

Fisting grouncts

Figure 4. Distribution of the catch by purse seiners by fishing grounds.

Sources: Redrawn from Potier \& Sadhotomo (1995)

fish accessibility. The catch data from the landing sites were collected, then categorized into seven geographical locations of the fishing grounds (Figure 3). Previous information (Potier \& Sadhotomo, 1995) revealed that most of the purse seiners were performed in the water with salinity above $32 \%$ with different fish species compositions.
The overall catch data of the dominant pelagic fish species during a period of 1990 to 1995 of the main fishing grounds (Figure 4) showed that the catches tend to increase in the fishing grounds around Bawean, Masalembo, Matasiri, and Kangean Islands. The highest catch were found in the waters around Matasiri Islands which clearly showed that those areas were highly influenced by the east west ward movement of 
the oceanic waters in the eastern part of the Java Sea.

Monthly catch rates of the dominant pelagic species from landings show a high seasonal cycle, which is more or less related to the monsoon (Potier

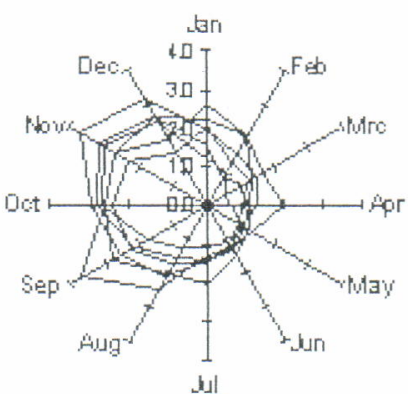

ul
\& Sadhotomo, 1995). The catch rates during a period of 1990 to 1995 clearly increase between Augusts to November (high salinity and low temperature) and then with a lower catch rates on December to July (Figure 5).

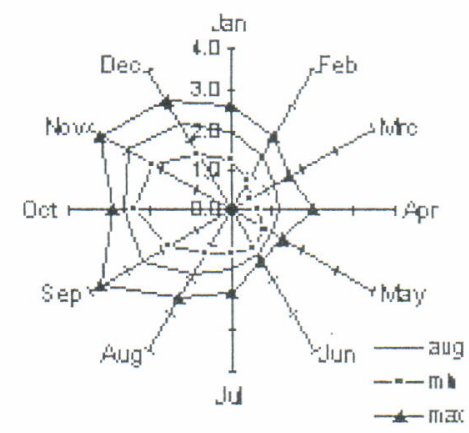

Figure 5. Monthly catch rates of pelagic species in the main fishing grounds during 1990 to 1995 Remarks: Left $=$ total catch; Right $=$ the average

Figure 6. The average density by cruises in the main fishing grounds.

\section{Population Density}

The population density was analyzed based on the acoustic abundance. The density (in unit of integration) fluctuated by the cruise. Even though the dense of population have been observed during the night in some situation but overall densities were higher during September to December and lower in a period of February to June (Figure 6).

These phenomena show relatively similar with the above average monthly catch data from purse seiners operated in the main fishing grounds. Situation was cifferent during December 1993, when the catch rates were low but the density still give a higher values. This could be explained from the echograms clearly show that the fish concentration performed in the deeper layer. This water column is and being unfishable by commercial fishing the fleet, due to limited obtainable information.
The longitudinal west east distribution show that the highest density occurred within period of September to December and continued with a series of lower density in the beginning of the year till June (Figure 7). However there still some higher values occurred in the eastern part which means that the population of pelagic fish is densely exist in the eastern part. In September until December, there is a general rising gradient abundance from west to east direction of the Java Sea.

Observation on fish schools dimension was done based on the data collected within a period of October, November 1993 and February 1994. The dimension of the schools represented by the values of the length $(\mathrm{m})$, height $(\mathrm{m})$ and estimated area $\left(\mathrm{m}^{2}\right)$ were obtained by applying software of Movies B developed by the IFREMER. The three parameters clearly show that there are differences among them between the cruises. The highest percentage of fish schools in 

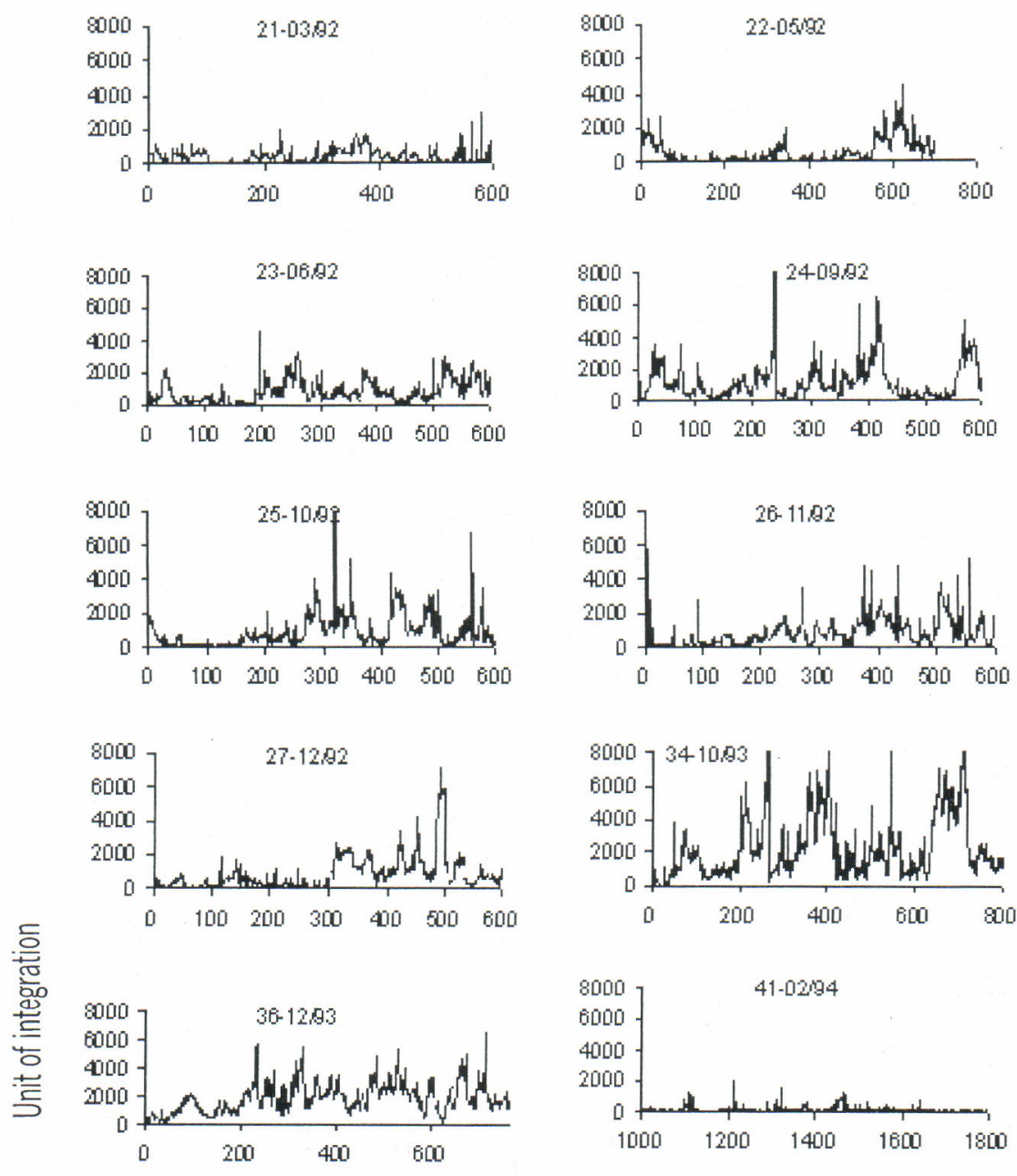

$\operatorname{ESDU}(\mathrm{nm})$

Figure 7. Longitudinal distribution of the west eastward density. Remarks: $0=$ approximately $110^{\circ} \mathrm{E}$ and $800=116^{\circ} \mathrm{E}$
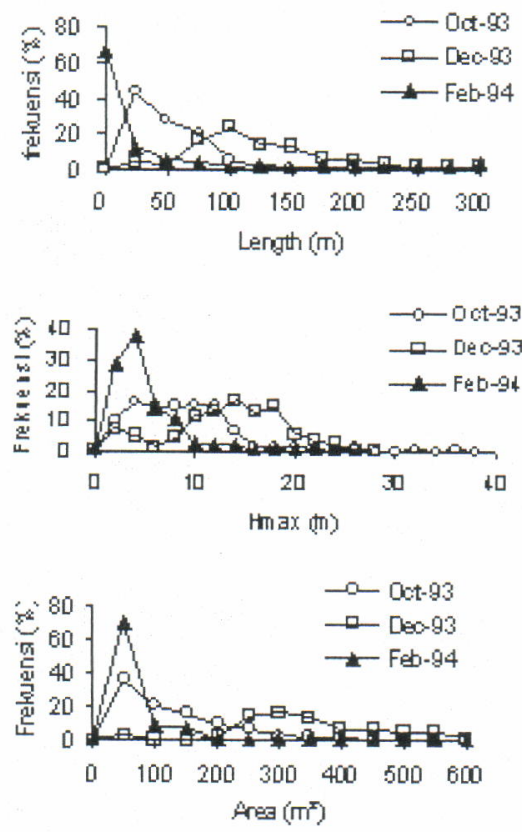

Figure 8. Fish school dimensions during October, November 1993, and February 1994. 
February was relatively smaller than others, and in December, the highest percentage occurred at around $100 \mathrm{~m}$ length, $20 \mathrm{~m}$ heights with around $300 \mathrm{~m}^{2}$ of fish school area.

Figure 8 indicates the fish school dimensions during three different cruise where the values of October 1993 are relatively between the values of December 1993 and February 1994 cruises.

\section{CONCLUSION}

1. The phenomena of acoustics observation in the Java Sea proved that the population of fish densities was higher in the period of late dry season between September to December and gradually decreased in the period of wet season (February to May). There is strong correlation between population densities and the longitudinal movement of high salinity waters, and the values of fish densities always tend to high in the eastern part of the Java Sea.

2. The results demonstrate that the seasonal variabilities of fish densities explain that most of the purse seiners shifted to the fishing ground beyond the Java Sea such as Southern part of the South China Sea and Makassar Strait at the end of wet season.

3. Fish schools observations confirmed that dispersion of the pelagic fish is relatively in low occurrence of fish schools. Therefore, fishing activities should be operated by driving fish schools into fish concentration by using concentration tactics such as fish aggregation Device, and setting the net at night by using light attraction technique

\section{ACKNOWEDGMENTS}

This paper is collaboration research by OrstomAARDRIMF Java Sea Pelagic Fishery Stock Assessment by the Orstom-European Union-Agency of Agriculture Research and Development the F.Y. 1991-1997.

\section{REFERENCES}

Boely, T., M. Potier, \& B. Sadhotomo. 1992. Evolution and pattern of a fishing system: the purse seiners of the Java Sea. Java Sea Pelagic Fishery Assessment Project. Sci. and Tech. Doc. 14. 4 p. ORSTOM/AARD.

Durand, J. R. 1997. Presentation of the pelfish project and the seminar akustikan 2. In Proceeding of Acoustics Seminar Akustikan 2. EU. CRIFIAARD. ORSTOM. Bandungan $27^{\text {th }}-29^{\text {th }}$ May, 1996 By Petit, D. P. Cotel, \& D. Nugroho. 1997 (eds). p. $11-13$

Mertha, I. G. S., S. Nurhakim, \& J. Widodo. 1998. Small pelagic fish resource. In Potency and distribution of marine fish resources in Indonesian waters. Nat. comm. On Marine Fish Stock Assessment. Lembaga IImu Pengetahuan Indonesia by Widodo et al. 1998 (eds.) p. 89-106.

Petit, D., P. Cotel, \& D. Nugroho. 1997. The pelfish surveys: Objectives and data collection. In Proceeding of Acoustics Seminar Akustikan 2. EU. CRIFI-AARD. ORSTOM. Bandungan 27-29 th May. p. $15-25$

Potier, M. \& B. Sadhotomo. 1995. Exploitation of the large and medium seiners fisheries. In Potier $\mathrm{M}$. \& S. Nurhakim (ed.) Biology, Dynamics, and Exploitation of the Small Pelagic Fishes in the Java Sea. AARD/ORSTOM. p.195-214

Veen, P. C. H. 1953. Preliminary charts of the mean salinity of the Indonesia archipelago and adjacent waters. Org. Sci. Resources Indonesia. 17. $46 \mathrm{p}$.

Wyrtki, K. 1961. Physical oceanography of the southeast Asian waters. Naga Report. Scripps Institute Oceanography University California. 2. 1-95. 